DOI: https://doi.org/10.24127/ajpm.v10i2.3660

\title{
THE ANALYSIS OF STUDENTS' CREATIVE THINKING SKILLS IN SOLVING OPEN ENDED QUESTIONS IN TERMS OF GENDER
}

\author{
Hana Shohwatul Islam ${ }^{*}$, Budiyono ${ }^{2}$, Siswanto ${ }^{3}$ \\ 1*Postgraduate Program of Mathematics Education, Universitas Sebelas Maret, Indonesia \\ ${ }^{2}$ Faculty of Teacher Training and Education, Universitas Sebelas Maret, Indonesia \\ ${ }^{3}$ Faculty of Mathematics and Natural Sciences, Universitas Sebelas Maret, Indonesia \\ *Corresponding author. \\ E-mail: $\quad$ hanashohwatul@student.uns.ac.id $^{\left.{ }^{*}\right)}$ \\ budiyono@staff.uns.ac.id ${ }^{2)}$ \\ sis.mipauns@yahoo.co.id ${ }^{3)}$
}

Received 02 April 2021; Received in revised form 14 June 2021; Accepted 29 June 2021

\begin{abstract}
Creative thinking is an ability that must be developed in learning mathematics. The purpose of this study was to analyze students' creative thinking in solving open-ended questions in terms of gender differences. The research method used is descriptive research with a qualitative approach. The data analysis technique in this study was data reduction, data display, dan conclusion drawing or verification. The research subjects were 6 seventh grade VII students of SMP N 3 Surakarta. The research instrument used was an open-ended questions with indicators of creative thinking and interviews. The results showed that in the aspect of fluency, female students were better than male students in producing ideas, on the flexibility aspect, female students and male students were able to achieve good flexibility aspects by providing varied problem solutions, and in the novelty aspect, female and male students can achieve the novelty aspect by giving different answers.
\end{abstract}

Keywords: Creative thinking; gender; open-ended.

\begin{abstract}
Abstrak
Berpikir kreatif merupakan kemampuan yang harus dikembangkan dalam pembelajaran matematika. Tujuan penelitian ini adalah untuk menganalisis kemampuan berpikir kreatif siswa dalam menyelesaikan soal open ended ditinjau dari perbedaan gender. Metode penelitian yang digunakan adalah penelitian deskriptif dengan pendekatan kualitatif. Teknik analisis data yang digunakan yaitu reduksi data, penyajian data, dan penarikan kesimpulan. Subjek penelitian adalah 6 siswa kelas VII SMP N 3 Surakarta. Instrumen penelitian yang digunakan yaitu soal open ended dengan indikator berpikir kreatif dan wawancara. Hasil penelitian menunjukan bahwa pada aspek kefasihan (fluency), siswa perempuan lebih baik dibandingkan siswa laki laki dalam memproduksi suatu gagasan, pada aspek fleksibilitas (flexibility) siswa perempuan dan laki laki mampu mencapai aspek fleksibilitas dengan baik dengan memberikan pemecahan masalah yang bervariasi, dan pada aspek kebaruan (novelty) siswa perempuan dan laki laki dapat mencapai aspek kebaruan dengan baik yaitu memberikan jawaban yang berbeda beda.
\end{abstract}

Kata Kunci: Berpikir kreatif; gender; open-ended.

This is an open access article under the Creative Commons Attribution 4.0 International License

\section{INTRODUCTION}

Education at this time is held to develop students' creativity in order to be able to meet their personal needs, as well as the needs of the community. (Noer, 2011) In the process of learning mathematics, a person will be trained to think creatively (Argarini, Budiyono, \& 
Sujadi, 2014; Irvani, 2017). In the 2013 curriculum the theme of curriculum development is a curriculum that can produce a productive, creative, innovative, affective of Indonesian through strengthening integrated attitudes, skills and knowledge. The ability to think creatively makes students more open in seeing mathematical problems and students not only think of one solution but many ways of solving mathematical problems (Ayu, Moharom, \& Zanthy, 2020). So that creative thinking is important to be developed in the realm of education, especially in learning mathematics.

Based on the results of the 2018 Program for International Student Assessment (PISA) study, Indonesia is ranked 7th from the bottom (73) with an average score of 379. Indonesia's performance appears to have decreased when compared to the 2015 PISA report. PISA results in 2015 stated that the ranking Indonesia is rising but still very low. Indonesia's ranking increased from 71 in 2012 to 64 in 2015 from 72 member countries of the Organization for Economic Cooperation and Development (OECD). This shows that the creative thinking of Indonesian students is still low. The low ability of students to think creatively is still found in many aspects of fluency, flexibility, originality and detail (Argarini et al., 2014; Noviyana, 2017; Saputra, 2016; Widiani, Rifat, \& Ijuddin, 2016) even though creative thinking emphasizes the aspects of fluency, flexibility, originality, and elaboration. Fluency can be identified from the number of relevant student responses. From these student responses, it can still be categorized into several categories which is related to the flexibility aspect. There is a possibility that the responses given by the students are many but it is only one category. The student response is said to be original if it is unique, unusual, and only done by very few students. The response is said to be detailed if the procedure is coherent, logical, clear, and reasoned. One of the ways to identify students' creative thinking is by using an open-ended test. The open-ended test triggers students' thinking because with the many ways that are obtained, students are not only fixated on 1 concept in solving math problems but they can have various ways of solving them and that makes them think creatively to solve these problems in their own way (Ayu et al., 2020; Maskur, Syazali, \& Utami, 2019). With an open-ended test, it is hoped that it can make the students to answer the problems in various ways, thus inviting the potential intellectual and students' experience in the process of finding something new.

There are many factors that influence students' creative thinking skills, one of them is gender. The gender factor was taken because it was suspected that there was a difference in ability between male students and female students. Gender is a characteristic that differentiates between individuals (Simanjuntak, Hia, \& Manurung, 2019). This gender difference makes people think whether the way of thinking, learning and conceptualization is different according to gender. Many previous studies have shown diversity in abilities due to gender roles (Kusumaningsih, Saputra, \& Aini, 2019; Susilowati, 2016; Tao \& Michalopoulos, 2020). Based on the results of the review above, it is known that it is important to analyze students' creative thinking abilities in terms of differences gender. From the previous researches, there have been many studies discussing students' creative 
thinking abilities (Anggoro, 2015; Argarini et al., 2014; Choridah, 2013; Kurniasari, Dwijanto, \& Soedjoko, 2014; Noviyana, 2017; Rahman, 2010; Saputra, 2016). Based on previous research that discusses creative thinking ability, some of them research by Anggoro (Anggoro, 2015) which states that students' creative thinking skills can be developed through module development with Problem Solving strategy. Choridah Research (Choridah, 2013) uses problem-based learning to improve students' creative thinking and communication skills and mathematical disposition. Further research that reviews abilities based on gender differences (Anggoro, 2016; C-Brandt, Ia, \& Tullney, 2016; Dewi1, Arini, Suhito, Mulyono, \& Masrukan, 2019; Diandita, Johar, \& Abidin, 2017; Fitriani, Jalmo, \& Yolida, 2015; Kusumaningsih et al., 2019; Lindberg, Hyde, Petersen, \& Linn, 2010; Maria Ulpa, 2014; Niederle \& Vesterlund, 2010; Rahayuningsih \& Feriyanto, 2018; Sagala, Umam, Thahir, Saregar, \& Wardani, 2019; Siswati, Susilo, \& Mahanal, 2016; Subarinah, 2013; Sukayasa, 2014; Tao \& Michalopoulos, 2020; UNESCO, 2013; Utami \& Anitra, 2020; Winata \& Friantini, 2020). Based on previous research that discusses gender differences, some of which are research by Anggoro (Anggoro, 2016) which analyzes junior high school students' perceptions of learning mathematics in terms of gender differences and mathematical creative thinking dispositions and concludes that male students have positive perceptions compared to female student. Research by Helena Mihaljevi' C-Brandt, Tullney, Marco (C-Brandt et al., 2016) who has conducted research on the effect of gender differences on mathematics learning.
However, there is still no research that analyzes the creative thinking skills of students of SMP N 3 Surakarta in solving open-ended questions in terms of gender differences. Therefore, the purpose of this study was to analyze students' creative thinking skills in solving open-ended questions on flatended material in terms of gender differences in grade VII students at SMP N 3 Surakarta.

\section{METHODS}

The research method used is a descriptive method with a qualitative approach. The subjects in this study were 6 students taken from class VII students of SMP N 3 Surakarta in the odd semester of the 2020/2021 school year. The technique of taking the subject uses purposive sampling. The purpose of selecting subjects by purposive sampling, which is research subjects in accordance with the phenomenon in the focus of the study (Creswell, 2012). The instrument in this study was a test of creative thinking skills that used open-ended questions, questions in the form of essay tests in order to see students' creative thinking. In this study, the data validity uses the triangulation method. Triangulation method emphasizes the use of different data collection methods or methods for the same data (Budiyono, 2017). The data analysis technique in this study was focused on during the process in the field along with data collection (Sugiyono, 2013). After the data is collected, can reduce the data or present the data. Data reduction and data presentation activities can be reciprocal, which means that they can reduce data first or can present data first. Data reduction and drawing conclusions are reciprocal. If after the conclusion is obtained, it is felt that they haven't been 
able to produce a convincing theory, then data collection is carried out again. However, after the research objectives are achieved and the research questions are answered, conclusions can be drawn. The stages in this research are:

1. Conduct observations to schools, determine research classes, determine the subjects used and develop research instruments in the form of tests.

2. Give a creative thinking test on flat building materials to grade VII students to find out how creative thinking skills students have and analyze the results of students' creative thinking tests in solving open ended problems.

3. Select two subjects that fulfill each indicator of creative thinking and have a high cognitive capability based on scoring values at high-value intervals of tests. The subject has been discussed with the teacher on the basis that the student has received a level build material, the student is able to communicate his or her mind both orally and well written, and the subject is willing to participate in the data retriever during the study.

4. Conduct interviews with students after the test is carried out. This interview is semi-structured, where a list of questions is prepared in advance that contains the main questions as a guide during the interview process.

\section{RESULT AND DISCUSSION}

The following are the results of the research as well as analysis of the data obtained. The results of the research are in the form of creative thinking tests students in solving openended problems on flat building materials and interviews that have been conducted, as follows :

\section{a. Fluency}

Question number 1 aims to measure the subject's fluency indicators in solving open-ended questions that require forming several rectangular shapes. The form of the question used can be seen in Figure 1.

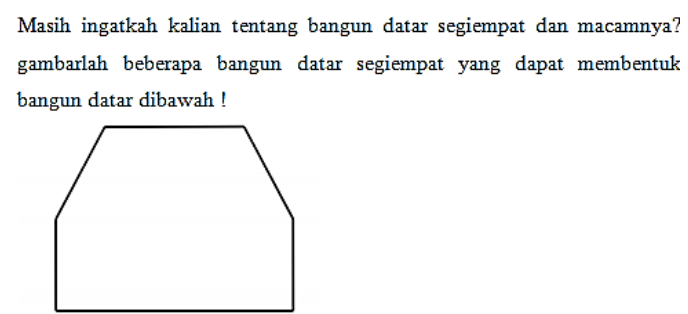

Figure 1. Test of fluency aspect

In the fluency indicator, students are expected to be able to produce ideas. Based on the test results of creative thinking in the fluency aspect, female students were able to achieve fluency aspects well. In Figure 2, it can be seen from the detailed answers of female students in answering questions, so they are able to produce ideas. Female students are able mention the name of two-dimensional figure. Meanwhile, male students were able to achieve fluency aspects, but were less than perfect in answering questions. This can be seen in Figure 3, from the answers of male students who are still incomplete in mentioning the names of twodimensional figures.

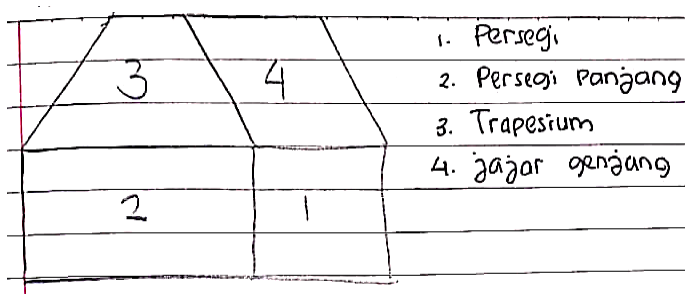

Figure 2. The female students' answer for fluency aspect 
DOI: https://doi.org/10.24127/ajpm.v10i2.3660

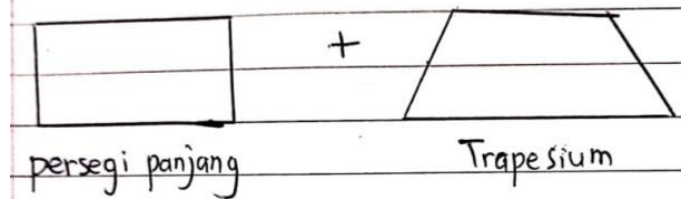

Figure 3. The male students' answer for

b. Flexibility

fluency aspect.

The subject is given a question about the problem of finding the area of a garden. Subjects are required to produce different answers. The question can be seen in the Figure 4.

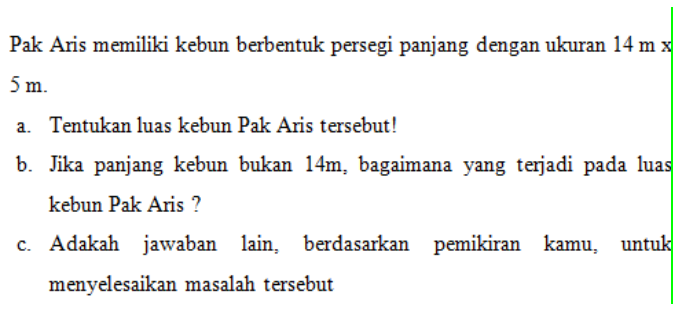

Figure 4. Test of flexibility aspect

In the flexibility aspect, students are expected to be able to solve problems in a variety of different ways. Based on the results of tests of creative thinking in the flexibility aspect, male and female students were able to achieve the flexibility aspect well. In Figure 5, it can be seen from the answers of female students who have no difficulty solving problems. In solving the problems in question Number 2 point (b) and (c), female students change the length of the garden to find different answers. Based on Figure 6, the male students' answers gave more than one different answer, which means that male students did not have difficulty in finding other ideas. Furthermore, it can be concluded that female students and male students are able to produce various ideas/ answers. The following are representatives of female and male students' answers on the aspect of flexibility.

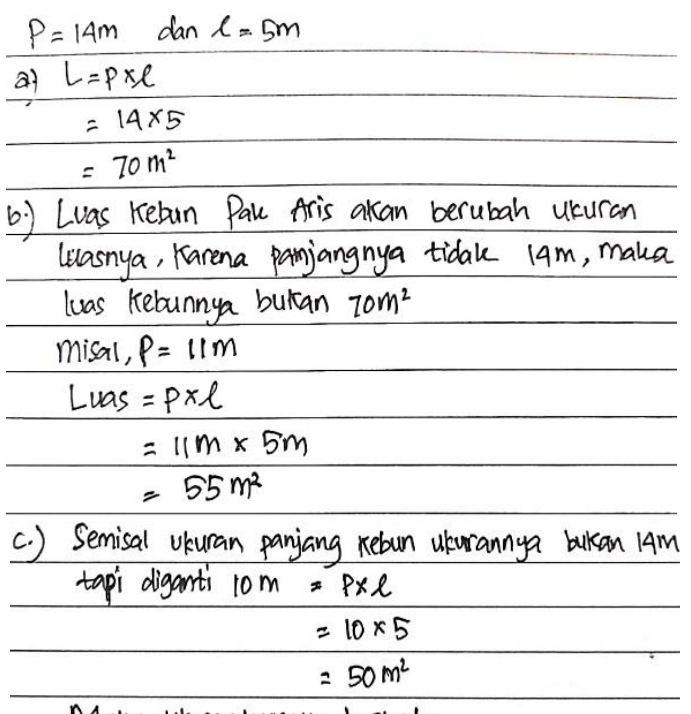

Maka ukuran luasnya berbeda.

Figure 5. The female students' answer for flexybility aspect

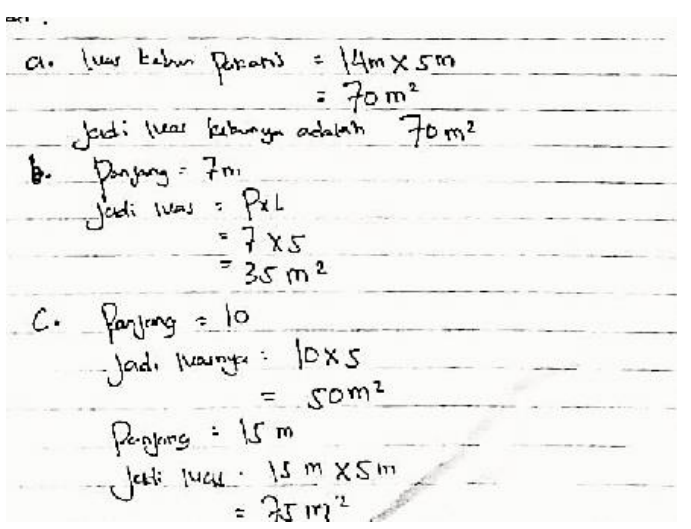

Figure 6 . The male students' answer for flexybility aspect

\section{c. Novelty}

The novelty question aims to measure the indicator of novelty in solving the problem. The subject is faced with the question of what flat shapes can be formed as much as possible, if the area is determined. Subjects are required to make another flat shape that is different and has the same area. The novelty question is "Gambarlah bangun datar yang bisa dibentuk sebanyak mungkin, jika diketahui luas masing-masing bangun adalah $100 \mathrm{~cm}^{2}$, . 
DOI: https://doi.org/10.24127/ajpm.v10i2.3660

In the novelty aspect, students are expected to be able to answer questions with several different answers. Based on the tests results of creative thinking in the aspect of flexibility, female students are able to achieve novelty aspects. In Figure 7, it can be seen from the female students' answers sheet that can make several different of shapes that have the same area. This shows that female students are able to answer questions with several different answers. However, it is not perfect to draw twodimensional figure of a trapezoid and a rectangle. In addition, female student did not provide symbol for the lower side length of the trapezoid. Meanwhile in Figure 8, it can be seen from the answer sheets that male students can solve the problem by creating a twodimensional space that is square, triangles and rectangles with the same area. Therefore, the male students have achieved the novelty aspect well. Following are the answers of male and female students in the novelty aspect.
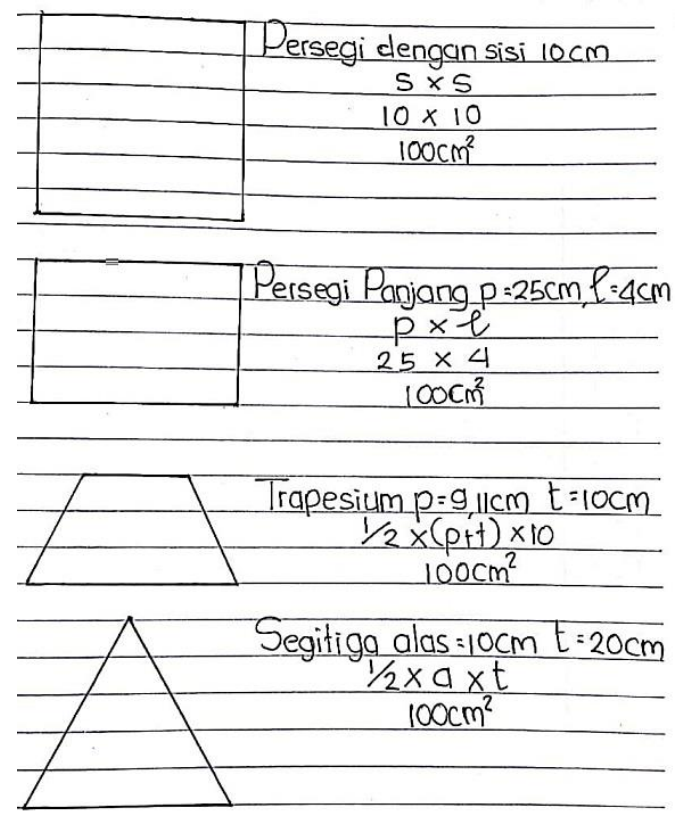

Figure 7. The female students' answer for novelty aspect

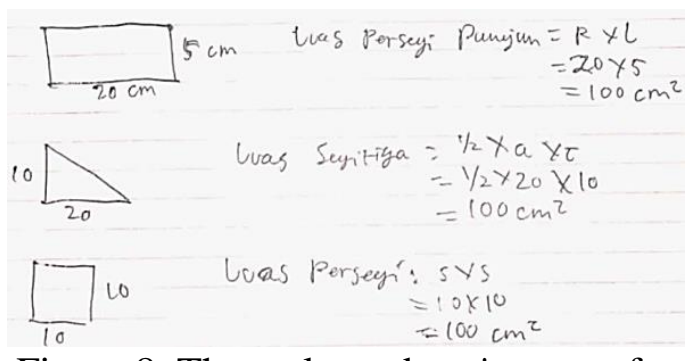

Figure 8 . The male students' answer for novelty aspect

Based on the research findings that have been described, it can be seen that in the fluency aspect, female students are better than male students in producing an idea. In the aspect of fluency, female students are able to name flat shapes in answering questions, while male students are not complete in mentioning flat shapes. For the flexibility aspect, female students and male students were able to achieve the flexibility aspect well by providing varied problem solving. For the novelty aspect, female and male students can achieve the novelty aspect well, namely giving different answers. Male and female students have different levels of creative thinking skills in each aspect, this study is in line with research by Erlinawaty Simanjuntak et al (Simanjuntak, Hia, \&Manurung, 2019) which states that gender influences creative thinking outcomes, female students are better at creative thinking than male students, where students who have different levels of thinking ability will also be different creative thinking.

It can be said that everyone has different creative potentials, both from the point of view and from the characteristics of their creative thinking. A person's creative thinking skills are influenced by personal characteristics, problem characters, and points of view. They can develop their creative potential by knowing in advance what characteristics of creative thinking skills 
stand out to them. Men and women generally have similar creative thinking characteristics, but in particular have differences in various aspects of their creative thinking skills. Men excel in certain aspects, while women also excel in other aspects. Each individual has the same potential to develop.

\section{CONCLUSION AND SUGGESTION}

The results showed that in the aspect of fluency, female students were better than male students in producing ideas. In addition, in the flexibility aspect both female and male students were able to achieve the flexibility aspect well by providing varied problem solutions. At last, in the novelty aspect both male and female students can achieve the novelty aspect well by giving different answers.

Every student has different characteristic, therefore teacher should be more pay attention to the selfefficacy all of students in the process learning. For the next research, it is better to use different material to find out the creative thinking process students. Moreover, it can use a subject that is high education to know the process creative thinking, so it can be seen if age affect the creativity someone.

\section{DAFTAR PUSTAKA}

Aizikovitsh-Udi, E. (2014). The Extent of Mathematical Creativity and Aesthetics in Solving Problems among Students Attending the Mathematically talented Youth Program. Creative Education, 5, $228-241$.

Anggoro, B. S. (2015). Pengembangan Modul Matematika Dengan Strategi Problem Solving untuk Mengukur Tingkat Kemampuan Berpikir Kreatif Matematis Siswa.
Al-Jabar: Jurnal Pendidikan Matematika, 6(2), 121-129.

Anggoro, B. S. (2016). Analisis

Persepsi Siswa SMP terhadap Pembelajaran Matematika ditinjau dari Perbedaan Gender dan Disposisi Berpikir Kreatif Matematis. Al-Jabar: Jurnal Pendidikan Matematika, 7(2), 153-166.

Argarini, D. F., Budiyono, \& Sujadi, I. (2014). Karakteristik Berpikir Kreatif Siswa Kelas VII SMP N 1 Kragan Dalam Memecahkan Dan Mengajukan Masalah Matematika Materi Perbandingan Ditinjau Dari Gaya Kognitif. JMME, IV(2), 112.

Ayu, L. S., Moharom, M. I., \& Zanthy, L. S. (2020). Analisis Kemampuan Berpikir Kreatif Matematis Siswa SMK Dalam Menyelesaikan Soal Open Ended. MAJU: Jurnal Ilmiah Pendidikan Matematika, 7(1), 8-17.

Budiyono. (2017). Pengantar Metodologi Penelitian Pendidikan. Surakarta: UNS Press.

C-Brandt, H. M., Ia, L. 1a S., \& Tullney, M. (2016). The Effect of Gender in the Publication Patterns in Mathematics. Plos One, 1-24.

Choridah, D. T. (2013). Peran pembelajaran berbasis masalah untuk meningkatkan kemampuan komunikasi dan berpikir kreatif serta disposisi matematis siswa SMA. Jurnal Ilmiah Program Studi Matrmatika STKIP Siliwangi Bandung, 2(2), 194-202.

Creswell, J. W. (2012). Educational research: Planning, conducting, and evaluating quantitative and qualitative research. Educational Research (Vol. 4). https://doi.org/10.1017/CBO97811 07415324.004 
Dewi1, N. R., Arini, F. Y., Suhito, S., Mulyono, M., \& Masrukan. (2019). Gender perspective in mathematical thinking ability. Journal of Physics: Conference Series, $1-5$. https://doi.org/10.1088/17426596/1321/2/022094

Diandita, E. R., Johar, R., \& Abidin, T. F. (2017). Kemampuan Komunikasi Matematis Dan Metakognitif Siswa SMP Pada Materi Lingkaran Berdasarkan Gender. Jurnal Pendidikan Matematika, 11(2), 79-97.

Fitriani, Y., Jalmo, T., \& Yolida, B. (2015). Hubungan Antara Gender Dengan Kemampuan Memecahkan Masalah. Jurnal Bioterdidik: Wahana Ekspresi Ilmiah, 3(5), 111.

Irvani, F. A. (2017). Profil Berpikir Kreatif Siswa Laki-laki dan Perempuan Kelas VIII-C SMP Nuris Jember dalam Menyelesaikan Soal Cerita Pokok Bahasan Segiempat. Skripsi Universitas Jember.

Kurniasari, I., Dwijanto, \& Soedjoko, E. (2014). Keefektifan Model Pembelajaran MMP Dengan Langkah Pemecahan Masalah Polya Terhadap Kemampuan Berpikir Kreatif Siswa. Unnes Journal of Mathematics Education, 3(2), 1-6.

Kusumaningsih, W., Saputra, H. A., \& Aini, A. N. (2019). Cognitive style and gender differences in a conceptual understanding of mathematics students. Journal of Physics: Conference Series, 1-6. https://doi.org/10.1088/17426596/1280/4/042017

Lindberg, S. M., Hyde, J. S., Petersen, J. L., \& Linn, M. C. (2010). New Trends in Gender and Mathematics
Performance: A Meta- Analysis. NIH Public Access, 136(6), 11231135. https://doi.org/10.1037/a0021276. New

Maria Ulpa. (2014). Gender Dalam Pembelajaran Matematika. YIN YANG., 9(2), 264-272.

Maskur, R., Syazali, M., \& Utami, L. F. (2019). Islamic-Nuanced Calculus Module with Open-Ended Approach in Real Number System Material. Journal of Physics: Conference Series, 1155(1), 12081. https://doi.org/10.1088/17426596/1155/1/012081

Niederle, M., \& Vesterlund, L. (2010). Explaining the Gender Gap in Math Test Scores: The Role of Competition. Journal OF Economic Perspectives, 24(2), 129-144.

Noer, S. H. (2011). Kemampuan Berpikir Kreatif Matematis Dan Pembelajaran Matematika Berbasis Masalah Open-Ended. Jurnal Pendidikan Matematika, 5(1), 1-8. Noviyana, H. (2017). Pengaruh Model Project Based Learning Terhadap kemampuan Berfikir Kreatif Matematika Siswa. Jurnal EDuMath, 3(2), 110-117.

Rahayuningsih, S., \& Feriyanto. (2018). Analisis Proses Berpikir Mahasiswa dalam Memecahkan Masalah Grup Ditinjau dari Gender. Jurnal Pendidikan: Teori, Penelitian, Dan Pengembangan, 3(12), 1672-1681.

Rahman, R. (2010). Pengaruh Pembelajaran Geogebra Terhadap Kemampuan Berpikir Kreatif dan Self-Concept Siswa. Tesis Pada SPS UPI. Tidak Dipublikasikan.

Sagala, R., Umam, R., Thahir, A., Saregar, A., \& Wardani, I. (2019). The Effectiveness of STEM-Based 
on GenderDifferences: The Impact of PhysicsConcept Understanding. European Journal of Educational Research, 8(3), 753-763. https://doi.org/http://doi.org/10.129 73/eu-jer.8.3.753

Saputra, P. R. (2016). Pembelajaran Geometri Berbantuan Geogebra dan Cabri Ditinjau dari Prestasi Belajar, Berpikir Kreatif dan SelfEfficacy. Jurnal Pendidikan Matematika, 11(1), 59-68.

Silver, E. A. (1997). Fostering Creativity through Instruction Rich in Mathematical Problem Solving and Thinking in Problem Posing. Electronic Edition, 29(3).

Simanjuntak, E., Hia, Y., \& Manurung, N. (2019). Analisis Kemampuan Berpikir Kreatif Dalam Pemecahan Masalah Ditinjau Dari Gender. School Education Journal, 9(3), 213-220.

Siswati, B. H., Susilo, H., \& Mahanal, S. (2016). Pengaruh Gender Terhadap Keterampilan Metakognitif dan Pemahaman Konsep Peserta Didik IPA dan Biologi di Malang. In Pros. Semnas Pend. IPA Pascasarjana $U M$ (pp. 748-755).

Subarinah. (2013). Profil Berpikir Kreatif Siswa dalam Memecahkan Masalah Tipe Investigasi Matematik Ditinjau dari Perbedaan Gender. In Seminar Nasional Matematika dan Pendidikan Matematika UNY (pp. 541-548). Yogyakarta: Universitas Negeri Yogyakarta.

Sugiyono. (2013). Metode Penelitian Kuantitatif, Kualitatif dan $R \& D$.

Sukayasa. (2014). Karakteristik Penalaran Siswa Smp Dalam Memecahkan Masalah Geometri Ditinjau Dari Perbedaan Gender. AKSIOMA : Jurnal Pendidikan
Matematika, 3(1), 81-90.

Susilowati, J. P. A. (2016). Profil Penalaran Siswa Smp Dalam Pemecahan Masalah Matematika Ditinjau Dari Perbedaan Gender. Jurnal Review Pembelajaran Matematika, 1(2), 132-148.

Tao, H.-L., \& Michalopoulos, C. (2020). Gender Equality And The Gender Gap In Mathematics. $J$. Biosoc. Sci., 50(3), 227-243. https://doi.org/10.1017/S00219320 17000141

UNESCO. (2013). UNESCO's Gender Mainstreaming Implementation Framework.

Utami, C., \& Anitra, R. (2020). Kemampuan Pemahaman Konsep Siswa Berdasarkan Gender pada Pembelajaran Realistic Mathematics Education Berbantuan Alat Peraga PANDU. Jurnal Kependidikan: Jurnal Hasil Penelitian Dan Kajian Kepustakaan Di Bidang Pendidikan, Pengajaran Dan Pembelajaran, 6(3), 475-489.

Widiani, T., Rifat, M., \& Ijuddin, R. (2016). Penerapan Pendekatan Saintifik Dan Pengaruhnya Terhadap Kemampuan Komunikasi Matematis Dan Berpikir Kreatif Siswa. Jurnal Pendidikan Dan Pembelajaran Khatulistiwa, 5(1), 1-14.

Winata, R., \& Friantini, R. N. (2020). Kemampuan Pemahaman Konsep Matematika Siswa Ditinjau Dari Minat Belajar Dan Gender. Journal of Mathematics Education, 6(1), 1-18. 